\title{
Enhanced Biogas Production From Winery Solid Waste Through Application Of Iron Oxide Nanoparticles
}

\author{
Carrelle G. Ossinga, Mahabubur R. Chowdhury and Vincent I. Okudoh
}

\begin{abstract}
Different methods and processes of optimizing the yield of biogas are currently being explored globally. In this study, the use of Iron oxide nanoparticles as an additive to improve the biogas production was carried out. Iron oxide nanoparticles (ION) were synthesized by hydrothermal method. And subsequently, the biomethane potential test was conducted in a $500 \mathrm{~mL}$ batch reactor set at mesophilic conditions for a retention time of 15 days. A combination ratio of $100 \mathrm{ppm}$ ION to $1.6 \mathrm{~g} / \mathrm{VS}$ winery solid waste (WSW) was used to run duplicate experiments. Results showed a cumulative biogas yield of $17,17 \mathrm{~mL} / \mathrm{g}$.VSadded for WSW alone (W1) compared to $56,93 \mathrm{~mL} / \mathrm{g}$.VSadded for the combination of WSW and ION (W2) which represents a biogas increase of $232 \%$. In conclusion, ION has chemical properties that boost biogas production irrespective of the type of substrate used. The finding is of interest to the biogas industry along with waste management practitioners.
\end{abstract}

Keywords - Anaerobic digestion, Biogas, Co-digestion, , Iron oxide nanoparticles, Winery solid waste

\section{INTRODUCTION}

The key challenges facing most countries in the $21^{\text {st }}$ century are environmental pollution and energy insecurities. The mitigation of greenhouse gas $(\mathrm{GHG})$ emissions require an investigation of alternative energy sources to reduce the dependence on fossils fuels[1]. Anaerobic digestion (AD) has been one of the well-studied technologies to tackle the challenges of increased energy demand and waste management. It has been proven to be suitable not only

Manuscript received the $7^{\text {th }}$ October. The financial assistance of the Mwalilu Nyerere African Union scholarship towards this research is acknowledged. Opinions expressed in this thesis and the conclusions arrived at, are those of the author, and are not necessarily to be attributed to the African Union committee.

C. Ossinga is with the Department of Chemical Engineering, Cape Peninsula University of Technology, Cape

Town, 7530 South Africa.

V. Okudoh is with the Department of Biotechnology and Bio Research Engineering Research Group, Cape Peninsula University of Technology, Cape Town, 8000 South Africa.

M. Chowdhury is with the Department of Chemical Engineering, Cape Peninsula University of Technology, Cape Town, 8000 South Africa. because of its limited environmental impacts but also for its high potential for energy recovery [2] and has led to several studies to improve biogas yield [3]. The biochemical process of anaerobic digestion has four steps namely: hydrolysis, acidogenesis, acetogenesis, and methanogenesis. Numerous microbes participate in the first three stages that finally lead to methane formation derived from acetate and hydrogen $/ \mathrm{CO}_{2}$ due to methanogenic archaea [4]. The methanogens play a key role in the carbon cycle by contributing to the degradation of organic waste mixture in an anaerobic environment as sewage, marshes or sediment [5]. Several studies on co-digestion, type of substrate [6] and pretreatment of biomass [2] by hydrolysis selectivity, have been carried out including heating the waste or addition of iron salt in a bid to increase the biogas yield [5].

Of all possible different feedstocks, winery solid waste (WSW) is suitable due to its availability, price, and generation potential. Grape wine is in continuous demand globally and South Africa is ranked amongst the top producing countries by contributing approximately 25 billion liters to the world market $[7,8]$.

Iron balance is essential for microorganism as it is for all living being. In fact, $\mathrm{Fe}^{2+}$ and $\mathrm{Fe}^{3+}$ ions are crucial for DNA replication and power generation amongst others. Iron ions effortlessly loose or gain electrons, which makes them suitable and a multi-purpose cofactor for a large number of protein functions. In contrast, a high amount of Iron produces toxic free radicals which is harmful to different biomolecules. Hence, a good Iron balance makes them a perfect advantage in microbial processes [5]. Their benefit in anaerobic digestion has been confirmed by Casals et al. [5] study on iron oxide nanoparticles using their distinctive properties to enrich the growth of microorganisms without any toxicity. According to the authors, a $180 \%$ increase of biogas production ( $234 \%$ increase in methane production) was achieved after 60 days retention time. The greatest amelioration to biogas production using nanoparticles to date.

Others studies made on nanomaterials revealed either negative or positive results with some very low biogas yields in some cases. Otero-Gonzales et al. [9] in 2014 investigated the effect of copper II oxide $(\mathrm{CuO})$ nanoparticles over a long-time period and demonstrated the inhibitive effect of 
$\mathrm{CuO}$ on methane production. In the addition, they observed a decrease of $15 \%$ on methane production. Similarly, Mu and Chen [10] and Gonzalez-Estrella et al. [11], confirmed the inhibitory effect of certain nanoparticles and metals oxides due to their toxicity on methane production. They respectively researched on zinc oxide $(\mathrm{ZnO})$ nanoparticles on the $\mathrm{AD}$ of waste-activated sludge and the effect of different metals oxides $\left(\mathrm{Al}_{2} \mathrm{O}_{3}, \mathrm{CeO}_{2}, \mathrm{CUO}, \mathrm{Fe}_{2} \mathrm{O}_{3}, \mathrm{Mn}_{2} \mathrm{O}_{3}\right.$, $\mathrm{TiO}_{2}, \mathrm{SiO}_{2}$ and $\mathrm{ZnO}$ ) on the $\mathrm{AD}$ process of Anaerobic Granular Sludge (AGS). They obtained for the first experiment a decreased biogas production of $81 \%$ and for the second, a decrease within the range of $52 \%$ and $87 \%$. Su et al. [12] study on Nano-zero-valence iron on the AD of waste activated sludge showed an increase in the biogas production by $30.4 \%$ and methane production by $40.4 \%$ confirming that nanoscale zero valent iron(nZVI) electron had a significant increase on biogas production.

Thus, we hypothesized that the utilisation of iron oxide nanoparticles (ION) as an additive to anaerobic digestion has the potential to enhance the biogas yield using dried substrates. Hydrothermal is a common method used to synthesize nanostructured materials as it provide a large range of shapes [13]. It is worth noting that, in anaerobic methanogenic conditions of the closed digester, added iron generates insoluble precipitates of ferric hydroxide which convert to $\mathrm{Fe}^{2+}$, soluble, and consequently becomes bioavailable[5].

\section{Methodology}

\section{A. Materials}

Fresh WSW was collected from a winery farm at the Agricultural Research Council (ARC), Stellenbosch, South Africa. It was sun dried and milled into powder form using a Hammer mill SER No. 400 (Scientific ${ }^{\circledR}$, SA) equipped with $2 \mathrm{~mm}$ sieve mesh [14]. Iron II chloride; Iron III Nitrate (nonahydrous); sodium dodecyl and ammonia were purchased from Sigma-Aldrich.

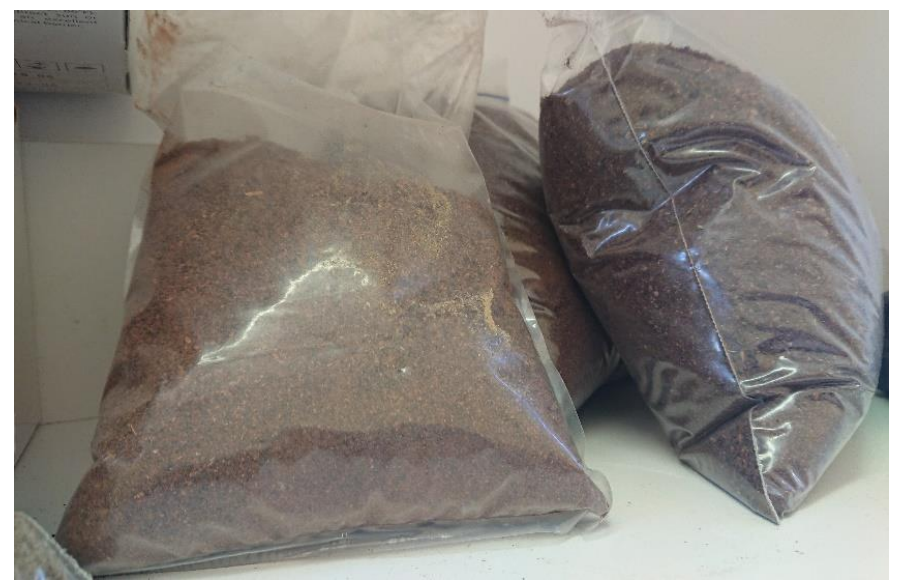

Fig. 1: Winery solid waste powder

\section{B. Inoculum}

A digestate from Cape Flats Wastewater AD treatment works in Cape Town, SA was used as inoculum.

The inoculum, which was $2 \mathrm{~L}$ digested sludge was mixed in $5 \mathrm{~L}$ plastic bottle with $1 \mathrm{~L}$ of pre-seed (previous inoculum prepared from another research already acclimatized with winery waste), $10 \mathrm{~g}$ of winery waste at once, and left to acclimatize. 1L of sterile distilled water was added to the mixture to make up the final $4 \mathrm{~L}$ volume. The inoculum slurry was incubated at $37^{\circ} \mathrm{C}$ in bath water for seven days and degassed daily. It is important to note that with this preparation a granular sludge was obtained. Therefore, before filling the bottles with samples, the inoculum was filtered using suitable sieve and the granules transferred in separate duplicate bottles [15].

\section{Analytical Methods}

The collected WSW substrate was analyzed for total solids (TS), volatile solids (VS), total nitrogen (TN), total organic carbon (TOC), calcium (Ca) and phosphorus (P), ash content and moisture content (MC). The TS and MC were determined by heating fresh biomass at $105{ }^{\circ} \mathrm{C}$ to a constant weight using Moisture Analyser Model MA35 (Sartorius GmbH, Germany). Merck Spectroquant Pharo® Spectrophotometer (Darmstadt, Germany) with Merck cell tests were used to determine the Total organic Carbon (cat no. 14879), Total Nitrogen content (cat no 14537) and total phosphorous (TP, cat no. 14729). Ash content was quantified by furnace method. All biomass analysis were carried out according to standard methods [16].

\section{Iron Oxide Synthesis}

The $\mathrm{Fe}_{3} \mathrm{O}_{4}$ nanoparticles was obtained by hydrothermal synthesis. 1,98g of Iron II chloride; 8,08g of Iron III Nitrate (nonahydrous); $0,7 \mathrm{~g}$ of sodium dodecyl; $100 \mathrm{~mL}$ of water and $10 \mathrm{~mL}$ of ammonia were mixed in an autoclave and then heated at $60^{\circ} \mathrm{C}$ for 4 hours. Hot water was used as heating substance.

The obtained solution was furthermore centrifuged for 5 $\min$ at $4000 \mathrm{rpm}$. This step was repeated until the resultant solution was clean.

\section{E. Biomethane Potential Experiment (BMP)}

Analytical BMP for this system was done in duplicates. Three experiments were done in Schott bottles with two connected screw cap GL 45 immersed in water bath system with temperature control (from FMH electronics model TR5 and serial number F7571-0717).

Six $500 \mathrm{~mL}$ Schott bottles were flushed with nitrogen before and after filling up with the substrate as well as the head space and the screw cap, for 1-2 minutes. Bottles 1-2 had inoculum only (control), 3-4 with inoculum WSW + ION and 5-6 inoculum + WSW only. $100 \mathrm{~mL}$ of sterile distilled water was added for a total working volume of $400 \mathrm{~mL}$. The inoculum/substrate ratio was $2: 1$ in terms of VS. Bottles were connected to the scrubbing system with the 
aid of silicone tubes. Each scrubbing system (bottle) was filled with water, $1 \mathrm{M}$ sodium hydroxide and phenolphthalein as indicator. The scrubbing system was then connected to a gasometer filled with acidified water ( $\mathrm{pH} \mathrm{1,} \mathrm{H}_{2} \mathrm{SO}_{4}, 30 \mathrm{~mL}$ ) and $10 \mathrm{~g}$ of table salt. Two holes were made in the gasometer cap, inlet and outlet entries, using silicone and vacuum grease to avoid air to go in. The biogas produced was collected by downward displacement of the acidified water and recorded in milliliters. Biomethane potential bottles were shaken twice daily to prevent scum and for homogenization inside the reactor.

TABLE I: SAMPLES INOCULATION

\begin{tabular}{lcccc}
\hline \hline & Units & Bottles 1-2 & Bottles 3-4 & Bottles 5-6 \\
\hline Inoculum & g.VSadded & 1.597 & 1.597 & 1.597 \\
\hline \hline $\begin{array}{l}\text { Winery } \\
\text { waste }\end{array}$ & g.VSadded & 0 & 1.547 & 1.547 \\
\hline \hline Iron oxide & $\mathrm{ppm}$ & 0 & 100 & 0 \\
\hline \hline Water & $\mathrm{mL}$ & 100 & 100 & 100 \\
\hline \hline
\end{tabular}

Temperature was checked daily and maintained at $37^{\circ} \mathrm{C}$ $+/-0.5$ with the aid of thermometer dipped in the water bath and also inside the bottle. The $\mathrm{pH}$ was checked at the beginning and the end of the run using a $\mathrm{pH}$ meter (Crison basic 20) at room temperature and adjusted when necessary using $1 \mathrm{M}$ sodium hydroxide $(\mathrm{NaOH})$ or $32 \%$ hydrochloric acid $(\mathrm{HCl})$. To maintain the water level in the bath water foam pieces have been added. Despite that, water was added regularly to maintain the level. Sodium hydroxide $(\mathrm{NaOH})$ or hydrochloric acid were used to correct the $\mathrm{pH}$ of the samples when needed. The experiment was run for 15 days.

\section{F. Biogas Collection And Measurement}

Biogas volume produced was collected and measured by displacement method using water column as represented in fig.2. Gas volumes recorded were converted to standards conditions. The net biogas volume is the biogas produced by inoculum and substrate deducted by the biogas produced by the inoculum only to account the biogas produced by inoculum. Biogas volume is then normalized by dividing the volume produced by gram of volatile solids (g.VSadded).

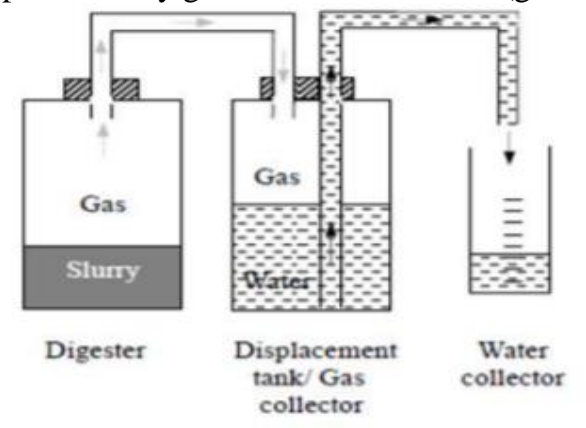

Fig. 2: Gasometer system used for biogas collection

\section{RESULTS AND DISCUSSION}

\section{A. Biomass Characterization}

Chemical composition and biodegradability are essential factors for the biogas and methane production [1]. Winery solid waste was characterized, and results are shown in Table 2. The substrate had a high content in total solids and volatile solids, with 95.92 and $83.86 \%$ respectively. Total volatile solids show the high ability of the feedstock for biodegradability and therefore biogas production rate. Nitrogen and Carbon content were found to be $1.76 \%$ and $50.40 \%$ respectively. Hence it gives a Carbon/ Nitrogen ratio of 28.63, which is acceptable. For high methane yield a Carbon/Nitrogen ratio between 20:1-30:1 is considered appropriate [17]. A protein content of $11 \%$ was also found. Substrates rich in protein give a relatively high biogas yield and are rich in energy. However, ammonia contained in protein is toxic for methanogenic bacteria at high concentration. Therefore, adequate amount of protein is required to provide enough nutrient without inhibiting the methanogens [1, 18]. A $28.05 \mathrm{mg} / \mathrm{kg}$ iron content was discovered in WSW. Trace of metals are essential in anaerobic digestion as it stimulate methanogenic activity. Some metals (Iron, Cobalt, Nickel, etc.) represent nutrient for methanogens [18]. Moisture content influences biogas production in anaerobic digestion. The higher the $\mathrm{MC}$, the higher the biogas yield [19]. WSW moisture content was found to be $1.15 \%$. Phosphorus $(0.16 \%)$, Potassium( $1.77 \%$ ) and Calcium(0.06\%) were found to be similar to Sousa [20] findings except for Calcium which was higher.

TABLE II: PROXIMATE AND UltimATE CHARACTERISTICS OF WiNERY SOLID WASTE

\begin{tabular}{c|cc}
\hline Characteristics & Units & Winery solid waste \\
\hline Moisture & $\%$ & 1.15 \\
Volatile solids & $\%$ & 83.86 \\
Total Solids & $\%$ & 95.92 \\
Total Nitrogen & $\%$ & 1.76 \\
Ash content & $\%$ & 15.950 \\
Total carbon & $\%$ & 50.40 \\
Calcium & $\%$ & 0.06 \\
Potassium & $\%$ & 1.77 \\
Phosphorus & $\%$ & 0.16 \\
Protein & $\%$ & 11.00 \\
Iron & $\mathrm{mg} / \mathrm{kg}$ & 28.05 \\
Sodium & $\mathrm{mg} / \mathrm{kg}$ & 1191.90 \\
Cyanide & $\mathrm{mg} / \mathrm{kg}$ & 0.92 \\
\hline \hline
\end{tabular}

\section{B. Biomethane Potential}

Biomethane potential on WSW+ION was analyzed for all samples and average values were taken. Table $\mathbf{3}$ shows the cumulative biogas produced and the normalized biogas (volume divided by volatile solids). Biogas production of 
WSW+ION (W1) started immediately on the first day as shown in Fig. 3. The combination of WSW+ION (W2) was still increasing while $\mathrm{W} 1$ became stable on day 11 .

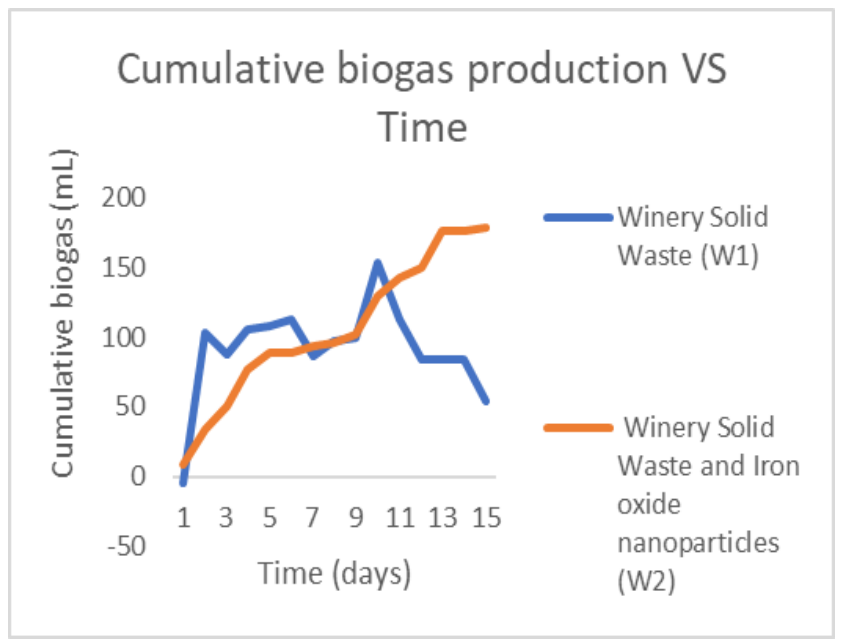

Fig. 3: Cumulative biogas production

W1 started producing a large volume of biogas in day 3 and later became regular until day 11 when it started to decrease. In contrast, W2 never decreased but continues increase on a regular basis. This may be due to insoluble $\mathrm{Fe}^{3+}$ ion generated at the start of the experiment which is later converted to $\mathrm{Fe}^{2+}$ leading to increased bioavailability, hence, boosting the production of biogas [5]. WSW contains carbohydrates, proteins and other minerals which could explain the high production on the early days. W2 produced about three time more biogas $(179 \mathrm{~mL})$ than W1 $(54 \mathrm{~mL})$, which confirms ION essential and versatile role as an additive nutrient of the nanoparticle as stipulated by Casals et al. [5]. Results are similar with Casals et al. [5](234\% biogas increase compared with $232 \%$ in this study). W1 biogas production could have dropped and have a lower biogas for several reasons. Firstly, its lignin-cellulose content (approx. 11\%) may restrict microbial degradation and therefore reduce biogas yield [21]. Secondly, the main antioxidant present in grape, (phenolics and its monomers) may have inhibitory effect on the bacteria thereby reducing the biogas production [22]. Their presence in winery waste was proved by Lafka et al. [23] using HPLC analysis for a total phenol content of $9.45(\% \mathrm{w} / \mathrm{w})$.

TABLE III: NoRMALIZED CUMULATIVE BIOGAS PRODUCTION FROM DIFFERENT SAMPLES SUBSTRATES: WINERY WASTE AND IRON OXIDE

\begin{tabular}{lcc}
\hline \hline Substrates & $\begin{array}{c}\text { Cumulative biogas } \\
\text { produced in } \mathrm{mL}\end{array}$ & $\begin{array}{c}\text { Cumulative biogas } \\
\text { produced in } \\
\text { mL/gVSadded }\end{array}$ \\
\hline WSW (W1) & 54 & 17,17 \\
\hline $\begin{array}{l}\text { WSW and Iron oxide } \\
\text { nanoparticles (W2) }\end{array}$ & 179 & 56,93 \\
\hline \hline
\end{tabular}

\section{CONCLUSION}

The application of Iron oxide nanoparticle at mesophilic conditions for anaerobic digestion on WSW showed satisfying results. WSW + ION showed the highest biogas production so far, which confirms its advantage in biogas production. However, WSW alone during digestion produced a lower biogas due to its adverse chemical properties. The following features will be further investigated on the additive nanoparticle in biogas production:

$>$ Termination of the current biomethane potential

$>$ Scanning electron microscopy and XRD pattern of Iron oxide

$>$ Chemical and physical properties of all the substrates

$>$ Optimization of biogas yield by testing three factors: Iron oxide concentration, Co-digestion in ratios and solid retention time

$>$ Quantitative and qualitative analysis of biogas produced

\section{ACKNOWLEDGMENT}

Carrelle G. Ossinga Author thanks go to the staff of Agricultural Research Council (ARC) Stellenbosch, CPUT and Cape Flats Wastewater Treatment works for their support.

\section{REFERENCES}

[1] Hagos, K., et al., Anaerobic co-digestion process for biogas production: Progress, challenges and perspectives. Renewable and Sustainable Energy Reviews, 2017. 76: p. 1485-1496. https://doi.org/10.1016/j.rser.2016.11.184

[2] Ariunbaatar, J., et al., Pretreatment methods to enhance anaerobic digestion of organic solid waste. Applied Energy, 2014. 123: p. 143-156. https://doi.org/10.1016/j.apenergy.2014.02.035

[3] Jenicek, P., et al., Potentials and limits of anaerobic digestion of sewage sludge: energy self-sufficient municipal wastewater treatment plant? Water Sci Technol, 2012. 66(6): p. 1277-81. https://doi.org/10.2166/wst.2012.317

[4] Gagliano, M.C., et al., Microbial diversity in innovative mesophilic/thermophilic temperature-phased anaerobic digestion of sludge. Environmental science and pollution research international, 2014. 22. https://doi.org/10.1007/s11356-014-3061-y

[5] Casals, E., et al., Programmed Iron Oxide Nanoparticles Disintegration in Anaerobic Digesters Boosts Biogas Production. Small, 2014. 10(14): p. 2801-2808. https://doi.org/10.1002/smll.201303703

[6] Pullen, T., Anaerobic Digestion - Making Biogas - Making Energy: The Earthscan Expert Guide. 2015: Taylor \& Francis. https://doi.org/10.4324/9781315770772

[7] Zacharof, M.-P., Grape Winery Waste as Feedstock for Bioconversions: Applying the Biorefinery Concept. Waste and Biomass Valorization, 2017. 8(4): p. 1011-1025. https://doi.org/10.1007/s12649-016-9674-2

[8] Da Ros, C., et al., Winery waste recycling through anaerobic co-digestion with waste activated sludge. Waste Management, 2014. 34(11): p. 2028-2035.

https://doi.org/10.1016/j.wasman.2014.07.017 
[9] Otero-González, L., J.A. Field, and R. Sierra-Alvarez, Inhibition of anaerobic wastewater treatment after long-term exposure to low levels of $\mathrm{CuO}$ nanoparticles. Water Research, 2014. 58: p. 160-168. https://doi.org/10.1016/j.watres.2014.03.067

[10] $\mathrm{Mu}, \mathrm{H}$. and Y. Chen, Long-term effect of $\mathrm{ZnO}$ nanoparticles on waste activated sludge anaerobic digestion. Water Research, 2011. 45(17): p. 5612-5620. https://doi.org/10.1016/j.watres.2011.08.022

[11] Gonzalez-Estrella, J., R. Sierra-Alvarez, and J.A. Field, Toxicity assessment of inorganic nanoparticles to acetoclastic and hydrogenotrophic methanogenic activity in anaerobic granular sludge. Journal of hazardous materials, 2013. 260: p. 278-285. https://doi.org/10.1016/j.jhazmat.2013.05.029

[12] Su, L., et al., Stabilization of sewage sludge in the presence of nanoscale zero-valent iron (nZVI): abatement of odor and improvement of biogas production. Journal of Material Cycles and Waste Management, 2013. 15(4): p. 461-468. https://doi.org/10.1007/s10163-013-0150-9

[13] Rao, B.G., D. Mukherjee, and B.M. Reddy, Chapter 1 - Novel approaches for preparation of nanoparticles, in Nanostructures for Novel Therapy, D. Ficai and A.M. Grumezescu, Editors. 2017, Elsevier. p. 1-36. https://doi.org/10.1016/B978-0-323-46142-9.00001-3

[14] Mkruqulwa, U., V. Okudoh, and O. Oyekola, Optimizing Methane Production from Co-digestion of Cassava Biomass and Winery Solid Waste Using Response Surface Methodology. Waste and Biomass Valorization, 2019 https://doi.org/10.1007/s12649-019-00801-y

[15] Amano, K., et al., Determination of Biogas Content in Biomass after Anaerobic digestion Laboratory Analytical Procedure (LAP). 2017.

[16] Angelidaki, I., et al., Defining the biomethane potential (BMP) of solid organic wastes and energy crops: a proposed protocol for batch assays. Water Sci Technol, 2009. 59(5): p. 927-34. https://doi.org/10.2166/wst.2009.040

[17] Lohani, S. and J. Havukainen, Anaerobic Digestion: Factors Affecting Anaerobic Digestion Process. 2018. 343-359. https://doi.org/10.1007/978-981-10-7413-4_18

[18] Rabii, A., et al., A Review on Anaerobic Co-Digestion with a Focus on the Microbial Populations and the Effect of Multi-Stage Digester Configuration. Energies, 2019. 12: p. 1106. https://doi.org/10.3390/en12061106

[19] Alnakeeb, A., K. Najim, and A. Ahmed, Anaerobic Digestion of Tomato Wastes from Groceries Leftovers: Effect of Moisture Content. International Journal of Transport Management, 2017.

[20] Sousa, E.C., et al., Chemical composition and bioactive compounds of grape pomace (Vitis vinifera L.), Benitaka variety, grown in the semiarid region of Northeast Brazil. Food Science and Technology, 2014. 34: p. 135-142. https://doi.org/10.1590/S0101-20612014000100020

[21] Sun, L., et al., The microbial community structure in industrial biogas plants influences the degradation rate of straw and cellulose in batch tests. Biotechnology for Biofuels, 2016. 9(1): p. 128. https://doi.org/10.1186/s13068-016-0543-9

[22] Kayembe, K., et al., Inhibitory effects of phenolic monomers on methanogenesis in anaerobic digestion. Br Microbiol Res J, 2013. 3: p. 32-41. https://doi.org/10.9734/BMRJ/2013/2291

[23] Lafka, T.-I., V. Sinanoglou, and E.S. Lazos, On the extraction and antioxidant activity of phenolic compounds from winery wastes. Food Chemistry, 2007. 104(3): p. 1206-1214.

https://doi.org/10.1016/j.foodchem.2007.01.068

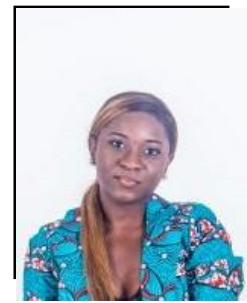

Carrelle G. Ossinga was born in Libreville, Gabon, $31^{\text {st }}$ August 1994. She obtained Btech in Chemical Engineering at Cape Peninsula University of Technology, Cape Town, South Africa in 2017. She co-wrote an article on Nanoparticle in 2016 untitled "Novel Sn Doped Co3O4 Thin Film for Nonenzymatic Glucose Bio-Sensor and Fuel Cell", published in 2017. She is currently a full time Master student at Cape Peninsula University of Technology working on renewable energy.

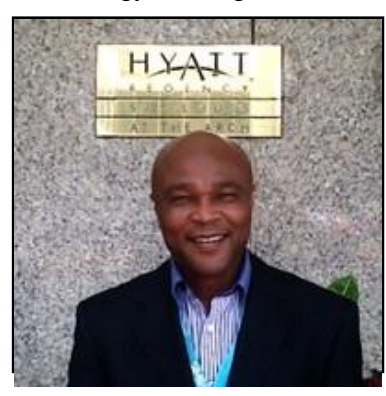

Dr. Vincent I. Okudoh completed his $\mathrm{MSc}$ and $\mathrm{PhD}$ in Industrial Microbiology at the University of KwaZulu-Natal (UKZN), Pietermaritzburg, South Africa in 2011. Up till 2013, he was a Postdoctoral Research Fellow at UKZN and a member of the African Energy, Food and Water Research (AEFWR) group under Prof Cristina Trois where he initiated a study on the quantification of cassava biomass as potential feedstock for biogas production. He joined the Cape Peninsula University of Technology (CPUT) as a Biotechnology Lecturer in 2013 and currently a Senior Lecturer. He is a co-principal investigator with the Bio-resource Engineering Research Group (BioERG). He has published many articles in top-rated peer-reviewed journals and conference proceedings. Dr Okudoh supervises a number of postgraduate students (2 $\mathrm{PhDs}$ and 5 Masters) and holds an NRF Thuthuka grant. He is a member of the Golden Key International Honor Society for top academic achievers and belong to professional organizations such as; American Society for Microbiology [ASM], Society for Industrial Microbiologists \& Biotechnology (SIMB) and South African Society for Microbiologists (SASM).

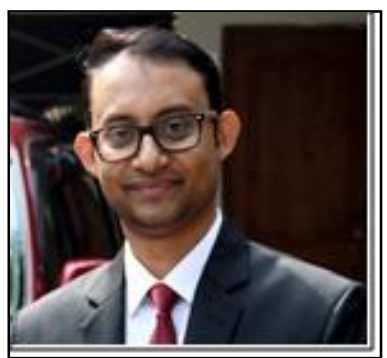

Dr. Mahabubur Rahman Chowdhury is a senior lecturer at the Cape Peninsula University of Technology. He is the leader of the functional materials research group (FMRG). He has a number of publications and patent. $\mathrm{He}$ is currently supervising fifteen MEng students and three postdocs. 